\title{
RANDOM NEURAL NETWORK LEARNING HEURISTICS - CORRIGENDUM
}

\author{
Abbas Javed, Hadi Larijani, Ali Ahmadinia and Rohinton Emmanuel
}

doi:10.1017/S0269964817000201, Published by Cambridge University Press, 22 May 2017.

The original publication of this article contained an error in the affiliation list.

The correct author and affiliation list is republished here.

Abbas Javed, Hadi Larijani and Rohinton Emmanuel

School of Engineering \& Built Environment, Glasgow Caledonian University, Glasgow, UK

Ali Ahmadinia

Department of Computer Science, California State University San Marcos, California, USA

The authors regret these errors.

\section{Reference}

1. Javed, A., Larijani, H., Ahmadinia, A., \& Emmanuel, R. (2017). Random Neural Network Learning Heuristics. Probability in the Engineering and Informational Sciences. doi:10.1017/S0269964817000201. 